\title{
R\&D Product Development KPIs and Performance of Companies in Serbia
}

\author{
Jelena TADIĆ, Ivana MEDVED, Ranko BOJANIĆ, Nemanja TASIĆ
}

\begin{abstract}
The main intent of the article is to explore whether assumed research and development (R\&D) product development key performance indicators (KPIs) are in relationship with a company's performance, as well as to determine the impact of R\&D product development KPIs to predicting company performance. The presented research was carried out on a sample of 196 manufacturing food companies in the Republic of Serbia. Statistical techniques of correlation and multiple regression analysis were applied. Results show that all analysed R\&D product development KPIs have significant impact on company performance displayed by ROA, ROE and EBITDA margin.
\end{abstract}

Keywords: company performance; KPI; product development; R\&D

\section{INTRODUCTION}

Recently, the meaning and researching of corporate Research and Development (R\&D) has notably expanded [1]. Enterprises have become very interested in studying out R\&D. That is the outcome of competition and greater influence of economic performance measurement [2]. The primary purpose of R\&D is to develop products that outsell existing market offerings or capture previously unknown market opportunities [3]. Corporate R\&D has been evaluated as an important factor [4] of improving company's performance for the sustainable competitive advantage improving, or design and development of the new products, services, processes, new patterns of improvement of existing products [2]. Furthermore, a company's internal experience of R\&D leads to the development of company-specific knowledge, and it becomes more likely that the desired benefits of innovation could be achieved at minimal cost [5]. Additionally, company's performance needs to be measured. A large number of accounting-based financial indicators has been considered as a very important measure for assessment of the company's performance [6]. In this study, the used accounting-based indicators for appraisal of a company's performance are: Return On Assets (ROA), Return on Equity (ROE) and Earnings Before Interest, Taxes, Depreciation and Amortization (EBITDA) divided by total revenue (EBITDA margin) [7].

The subject of the research is $R \& D$ product development performance measurement with associated KPIs and performance of company. This paper proposes a conceptual model for investigating a relationship between the assumed R\&D product development KPIs and company performance, as well as determining the effect of R\&D product development KPIs to predicting company's performances. The relationship between current R\&D product development and company's performance can be better if management implements and uses better key performance indicators (KPIs) of R\&D product development within the company. The effect of R\&D product development on a company's performance will largely depend on the top management ability to establish effective and efficient KPIs for measuring and managing R\&D product development [8]. The novelty in the research is reflected in the study of the significance of $R \& D$ product development KPIs that, so far, has not been sufficiently explored.
This research is important for several reasons. The findings have practical implications for the managers of companies in the sense of formulating more desired scenario to enhance their R\&D performance. In that way, such strategic steps lead to more innovative company, which is the key precondition for success. The theoretical contribution of the results is very valuable because it provides the comprehensive basis allowing additional testing of the similar or same topics.

This work is organised in five sections: second section focuses on previous studies that highly motivated us for this work, third part gives the details of the paper methodology. Results and discussions are presented in part four. In addition, the fifth part contains the main conclusions and proposes direction for future empirical work.

\section{LITERATURE REVIEW}

In the light of the increasing demand for efficiency and effectiveness in a growing information-based environment, the ability to acquire and act on performance information is often viewed as a condition for business success [9]. System of performance measurement can be explained as one of the most interesting managerial innovations over the last few years, because it is an important organizationalinformation link between strategic planning and operational control [10]. Performance measurement system is a system that expresses business strategies into desired output by integrating different business measures to set up how effectively a company obtains its goals [11]. Performance measurement represents the determination of the achievement of the set goals through the development of indicators and their connection with the goals and standards [12]. Therefore, key performance indicators (KPIs) show a way to realize dramatic performance improvements. KPIs determine measures of some particular parts of organizational performance that are critical to the current and future success of an enterprise [13-15]. KPIs have the advantage of measuring performance at stakeholders', projects and organisational level [16]. Outcomes of KPIs are the base for management and financial accounting reporting, such as mandatory, public reporting or internal reporting inside management structure[17].

The most important determinant of the company productivity is R\&D. For that reason, R\&D performance 
measurement is the basis of attention of R\&D managers. Wide number of authors have investigated and pointed out different R\&D measurements and determinants of R\&D performance [18]. $R \& D$ is a challenge for any manufacturing company in order to achieve a sustainable competitive advantage. For this purpose, the question arises of the efficiency and productivity of the $R \& D$ conducted. The selection of relevant indicators and metrics to measure $R \& D$ performance is the first line of focus in the research flow of performance measurement [19].

Business theory and practice, for the last thirty years, has explored the extent of the KPIs product development impact on $R \& D$ in corporations. Therefore, proving the positive impact of $R \& D$ on company performance has been intensified [20-27]. According to the market or book values of the companies, it is possible to evaluate the economic performance. These values are related but targeted at different components. Market evaluation of a company is focused on the economic perspective of the company or the quality of management. Company book value is a realistic measure of a company's economic life. [28]. Many empirical studies have found that different indicators are used in measuring a company performance. The most common indicators for measuring a company performances are $\operatorname{ROA}$ and $\operatorname{ROE}[6,29,30]$. Those are measures of financial performance of an entity, very important for investors. ROA is showing well the uses of company assets. Also, attention is put on accomplished profitability in context of using total assets of company. Final use of ROA number is to get a higher number because the company is earning more money on less investment [31]. ROE and EBITDA are very important in measuring a company's financial performance. ROE measures the ability of company management to generate profits and is calculated by dividing net income by share capital [32]. EBITDA is most commonly reported as a percentage of total company revenue and is intended to measure the company's operating profitability and cash flow for, above all, business owners and investors [33].

\section{RESEARCH METHODOLOGY}

The population of this study consists of firms in the manufacturing food sector in Serbia. In 2016, 3192 business entities were registered [34]. After the disposal of 2413 micro enterprises from manufacturing food companies in the Republic of Serbia, the population consists of 779 business entities. Empirical study included a sample of 196 manufacturing food companies of the Republic of Serbia. This is a stratified proportional sample, as a type of random sample $[35,36]$. Because of the relatively large and heterogeneous population, where it is not possible to determine each unit within the population, the sample is selected, with the population divided into strata, within which the monitoring units are selected. The selected feature that served as the basis for stratification is the size of the company. The questionnaire survey was realized in the period from January to March 2018. Questionnaire was sent to executive directors of the companies. The sample size in relation to population is 0,25 .

The first two metrics are input metrics, while others are output metrics. The key measure of $R \& D$ is headcount.
While the unit of production capacity is equipment in operations, in $R \& D$, the unit of production capacity is people. People represent the best measure of R\&D capacity [37]. Most manufacturing companies include this KPI. Reason for that is that often the biggest cost is employees and it is important for product development. Reinvestment in $R \& D$, i.e. how much the company will spend on $R \& D$ varies by type of industry, strategy of the company, and the competition and is measured by the percentage of sales [37]. The third metric is new product sales, which is calculated as a percentage of current year's sales of new products launched in the previous, most often, three years [37]. The production of patents, as a fourth metric, requires the patenting obligation to protect the invention in a timely manner [37]. The fifth metric is the launching of new products, which is closely related to the third metric, i.e. with revenues from sales of new products [37].

Respondents rated the significance of R\&D product development KPIs from 1 to 100 . For easier interpretation, the results were converted to a percentage. Descriptive statistical analysis of R\&D product development KPIs is displayed in Tab. 1.

Table 1 Descriptive statistical analysis of R\&D product development KPIs

\begin{tabular}{|c|c|c|c|c|c|c|}
\hline & $N$ & Min & Max & Mean & Std. & Variance \\
\hline $\begin{array}{c}\text { R\&D } \\
\text { headcount }\end{array}$ & 196 &, 10 &, 98 &, 538 &, 217 &, 048 \\
\hline $\begin{array}{c}\text { R\&D } \\
\text { spending }\end{array}$ & 196 &, 11 &, 98 &, 485 &, 213 &, 046 \\
\hline $\begin{array}{c}\text { New } \\
\text { product } \\
\text { sales }\end{array}$ & 196 &, 10 &, 96 &, 523 &, 215 &, 047 \\
\hline $\begin{array}{c}\text { Patent } \\
\text { production }\end{array}$ & 196 &, 14 &, 97 &, 591 &, 220 &, 048 \\
\hline $\begin{array}{c}\text { New } \\
\text { product } \\
\text { released }\end{array}$ & 196 &, 10 &, 97 &, 482 &, 224 &, 050 \\
\hline
\end{tabular}

All R\&D product development KPIs have roughly the same mean value, which means that companies give them approximately the same importance. Minimum value is approximately 0,1 while maximum value is approximately 0,9 . Based on the application of the scatterplot matrix, a lack of linear connectivity within $R \& D$ product development KPIs was found, i.e. R\&D product development KPIs can be used as regressors in a linear regression model.

In the case of the application of the standard multiple regression model used in this paper, all independent $R \& D$ product development KPIs are included in the model together, since the aim of the analysis is to examine the relation between the set of predictors (all independent variables) and dependent variable (performances of company). ROA, ROE and EBITDA margin, as indicators of the performance of the company, were selected because of their wide applicability in foreign and domestic research, and because they are yield indicators. Descriptive statistical analysis of company performances (continuous dependet variables) are displayed in Tab. 2.

Table 2 Descriptive statistical analysis of company performances

\begin{tabular}{|c|c|c|c|c|c|c|}
\hline & $N$ & Min & Max & Mean & Std. & Variance \\
\hline ROA & 196 &,- 342 &, 474 &, 052 &, 139 &, 019 \\
\hline ROE & 196 &,- 321 &, 531 &, 084 &, 141 &, 020 \\
\hline $\begin{array}{c}\text { EBITDA } \\
\text { margin }\end{array}$ & 196 &,- 290 &, 593 &, 124 &, 144 &, 021 \\
\hline
\end{tabular}


Minimum values are approximately $-0,3$ while maximum values are approximately 0,5 . The mean value of performance indicators of the company is $0,052,0,084$ and 0,124 , respectively [38]. Kolmogorov-Smirnov and Shapiro-Wilk's test were used for testing normality of distribution. If the amount of significance is greater than 0,05 , then the assumption of normality of distribution is confirmed [39]. In the analysed company performance indicators, the assumption of distribution normality is confirmed.

Based on a comprehensive review of literature dealing with the issues and objectives of this study, there are two research hypotheses:

$H_{1}$ : There is significant correlation between $R \& D$ product development KPIs and company performances.

$\mathrm{H}_{2}$ : Assumed $\mathrm{R} \& D$ product development KPIs have a significant impact on company performances.

Testing of the first hypothesis will be conducted using Pearson's correlation, while testing of the second hypothesis will be performed using standard multiple regression in the SPSS IBM statistical package, version 21.

\section{RESULTS AND DISCUSSION}

For investigation of a relationship between $R \& D$ product development KPIs and company performances (ROA, ROE, EBITDA margin) the Pearson linear correlation coefficient ( $r$ ) will be used (see Tab. 3).

Table 3 Correlation of R\&D product development KPIs with company performances

\begin{tabular}{|c|c|c|c|c|}
\hline \multicolumn{2}{|c}{} & ROA & ROE & $\begin{array}{c}\text { EBITDA } \\
\text { margin }\end{array}$ \\
\hline \multirow{2}{*}{$\begin{array}{c}\text { R\&D } \\
\text { headcount }\end{array}$} & $\begin{array}{c}\text { Pearson } \\
\text { Correlation }\end{array}$ &, 140 &, $142^{*}$ &, $142^{*}$ \\
\cline { 2 - 5 } & Significance &, 051 &, 047 &, 047 \\
\hline \multirow{2}{*}{ R\&D spending } & $\begin{array}{c}\text { Pearson } \\
\text { Correlation }\end{array}$ &, $177^{*}$ &, $165^{*}$ &, $152^{*}$ \\
\cline { 2 - 5 } & Significance &, 013 &, 021 &, 033 \\
\hline \multirow{2}{*}{$\begin{array}{c}\text { New product } \\
\text { sales }\end{array}$} & $\begin{array}{c}\text { Pearson } \\
\text { Correlation }\end{array}$ &, $326^{* *}$ &, $325^{* *}$ &, $320^{* *}$ \\
\cline { 2 - 5 } & Significance &, 000 &, 000 &, 000 \\
\hline \multirow{2}{*}{$\begin{array}{c}\text { Patent } \\
\text { production }\end{array}$} & $\begin{array}{c}\text { Pearson } \\
\text { Correlation }\end{array}$ &, $300^{* *}$ &, $294^{* *}$ &, $285^{* *}$ \\
\cline { 2 - 5 } & Significance &, 000 &, 000 &, 000 \\
\hline \multirow{2}{*}{$\begin{array}{c}\text { New product } \\
\text { released }\end{array}$} & $\begin{array}{c}\text { Pearson } \\
\text { Correlation }\end{array}$ &, $302^{* *}$ &, $286^{* *}$ &, $269^{* *}$ \\
\cline { 2 - 5 } & Significance &, 000 &, 000 &, 000 \\
\hline **Significant at the 0.01 level & & \\
\hline *Significant at the 0.05 level & & \\
\hline
\end{tabular}

The correlation between R\&D headcount and company performances is significant $(p<0,05)$ and slightly positive [40]. Small number of R\&D headcounters is associated with low values of ROA, ROE and EBITDA margin. The correlation between R\&D spending and company performances is significant $(p<0,05)$ and slightly positive. Small R\&D spending is associated with low values of ROA, ROE and EBITDA margin. The correlation between new product sales and company performances is significant $(p<0,01)$ and medium positive. A high level of new product sales is associated with high values of ROA, ROE and EBITDA margin. The correlation between patent production and company performances is significant $(p<0,01)$ and medium positive. High level of patent production is associated with high values of ROA, ROE and EBITDA margin. The correlation between new product releases and company performances is significant $(p<0,01)$ and small to medium positive. The relatively high level of new product releases is associated with relatively high values of ROA, ROE and EBITDA margin.

Given that three of five analysed R\&D product development KPIs have a weak to medium positive correlation with company performances, it can be concluded that hypothesis $H_{1}$ : There is significant correlation between $R \& D$ product development KPIs and company performances, is accepted.

\begin{tabular}{|c|c|c|c|c|}
\hline & $R$ & $R$ Square & $\begin{array}{c}\text { Adjusted } R \\
\text { Square }\end{array}$ & $\begin{array}{c}\text { Std. Error of the } \\
\text { Estimate }\end{array}$ \\
\hline ROA &, $524^{\mathrm{a}}$ &, 274 &, 255 &, 120 \\
\hline ROE &, $508^{\mathrm{a}}$ &, 258 &, 239 &, 123 \\
\hline $\begin{array}{c}\text { EBITDA } \\
\text { margin }\end{array}$ &, $488^{\mathrm{a}}$ &, 238 &, 218 &, 127 \\
\hline
\end{tabular}

a) Predictors: R\&D headcount, R\&D spending, new product sales, patent production, new product released

b) Dependent variables: ROA, ROE, EBITDA margin

Table 5 ANOVAa

\begin{tabular}{|c|c|c|c|c|c|c|}
\hline \multicolumn{2}{|c|}{ Model } & $\begin{array}{l}\text { Sum of } \\
\text { Squares }\end{array}$ & $d f$ & $\begin{array}{c}\text { Mean } \\
\text { Square }\end{array}$ & $F$ & Sig. \\
\hline \multirow{3}{*}{$\underset{\sim}{\mathbb{2}}$} & Regression & 1,042 & 5 & ,208 & 14,362 &, $000^{\mathrm{b}}$ \\
\hline & Residual & 2,758 & 190 & ,015 & & \\
\hline & Total & 3,800 & 195 & & & \\
\hline \multirow{3}{*}{ 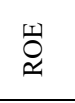 } & Regression & 1,005 & 5 & ,201 & 13,234 &, $000^{\mathrm{b}}$ \\
\hline & Residual & 2,884 & 190 & ,015 & & \\
\hline & Total & 3,889 & 195 & & & \\
\hline \multirow{3}{*}{ 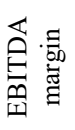 } & Regression & ,973 & 5 & , 195 & 11,892 &, $000^{\mathrm{b}}$ \\
\hline & Residual & 3,109 & 190 & ,016 & & \\
\hline & Total & 4,082 & 195 & & & \\
\hline
\end{tabular}

a) Dependent variable: ROA, ROE, EBITDA margin

b) Predictors: $R \& D$ headcount, $R \& D$ spending, new product sales, patent production, new product released

Testing of the second research hypothesis was performed by using multiple regression. In the Model Summary table are displayed proportions of variance accounted for dependent variables (ROA, ROE, EBITDA margin) by the predictor variables ( $\& \& D$ headcount, $R \& D$ spending, new product sales, patent production, new product released). The predictor variables have explained $27,4 \%$ variance of ROA (see $R$-square value in Tab. 4 ). The predictor variables have explained $25,8 \%$ variance of ROE. The predictor variables have explained $23,8 \%$ variance of EBITDA margin.

The ANOVA table shows the results of testing the null hypothesis that $R$-square equals zero, i.e. that there is no linear dependence between the predictors and the dependent variables [41]. By looking at the dependent variables ROA, ROE and EBITDA margin, it can be seen that the significance level is less than 0,01 and the $F$ statistics are 14,362, 13,234 and 11,892 respectively. Therefore, the null hypothesis is rejected.

Standardized Beta coefficient between the predictor variables (R\&D headcount, $R \& D$ spending, new product sales, patent production, new product released) and the dependent variables (ROA, ROE, EBITDA margin) is presented in Tab. 6. Tolerance values greater than 0,10 and variance inflation factor less than 10 [41] indicate that there is no multicollinearity problem. 
It can be determined that new product released $(0,288$; $0,271 ; 0,255)$ has the strongest impact on ROA, ROE and EBITDA margin, whereas the other R\&D product development KPIs are weaker: patent production $(0,273$; $0,265 ; 0,252), \mathrm{R} \& \mathrm{D}$ spending $(0,195 ; 0,181 ; 0,169)$, new product sales $(0,160 ; 0,166 ; 0,167)$ and $R \& D$ headcount $(0,134 ; 0,133 ; 0,130)$. Since the significance of all five KPIs is less than 0,05 , it can be concluded that $R \& D$ product development KPIs have a significant impact on the $\operatorname{ROA}(t=14,362, p<0,05), \operatorname{ROE}(t=13,234, p<0,05)$ and EBITDA margin $(t=11,892, p<0,05)$, as dependent variables. Given that all predictors have a significant impact on dependent variables, it can be concluded that hypothesis $\mathrm{H}_{2}$ : Assumed $\mathrm{R} \& D$ product development $K P I s$ have a significant impact on company performances, is accepted.

Table 6 Coefficients of company's performances (ROA, ROE, EBITDA margin)

\begin{tabular}{|c|c|c|c|c|c|c|}
\hline \multirow{2}{*}{\multicolumn{2}{|c|}{ Model }} & \multirow{2}{*}{$\begin{array}{c}\text { Standardized } \\
\text { Coefficients } \\
\text { Beta }\end{array}$} & \multirow{2}{*}{$t$} & \multirow{2}{*}{ Sig. } & \multicolumn{2}{|c|}{$\begin{array}{l}\text { Collinearity } \\
\text { Statistics }\end{array}$} \\
\hline & & & & & $\begin{array}{c}\text { Toleran } \\
\text { ce }\end{array}$ & VIF \\
\hline \multirow{6}{*}{ 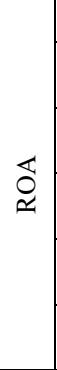 } & (Constant) & & $-6,651$ & , 000 & & $-6,651$ \\
\hline & $\begin{array}{c}\text { R\&D } \\
\text { headcount }\end{array}$ & ,134 & 2,090 & ,038 & ,134 & 2,090 \\
\hline & $\begin{array}{c}\mathrm{R} \& \mathrm{D} \\
\text { spending }\end{array}$ & , 195 & 3,093 & ,002 & , 195 & 3,093 \\
\hline & $\begin{array}{c}\text { New product } \\
\text { sales }\end{array}$ & , 160 & 2,385 & ,018 & , 160 & 2,385 \\
\hline & $\begin{array}{c}\text { Patent } \\
\text { production }\end{array}$ & ,273 & 4,275 & ,000 & ,273 & 4,275 \\
\hline & $\begin{array}{c}\text { New product } \\
\text { released }\end{array}$ & ,288 & 4,529 & , 000 & 288 & 4,529 \\
\hline \multirow{6}{*}{ 됭 } & (Constant) & & $-5,661$ & ,000 & & $-5,661$ \\
\hline & $\begin{array}{c}\text { R\&D } \\
\text { headcount }\end{array}$ & ,133 & 2,050 & ,042 & ,133 & 2,050 \\
\hline & $\begin{array}{c}\mathrm{R} \& \mathrm{D} \\
\text { spending }\end{array}$ & ,181 & 2,847 & ,005 & 181 & 2,847 \\
\hline & $\begin{array}{c}\text { New product } \\
\text { sales }\end{array}$ & ,166 & 2,443 & ,015 & 166 & 2,443 \\
\hline & $\begin{array}{c}\text { Patent } \\
\text { production }\end{array}$ & ,265 & 4,106 & , 000 & ,265 & 4,106 \\
\hline & $\begin{array}{c}\text { New product } \\
\text { released }\end{array}$ & ,271 & 4,214 & ,000 & ,271 & 4,214 \\
\hline \multirow{6}{*}{ 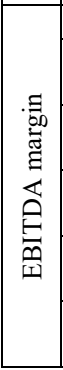 } & (Constant) & & $-4,486$ & ,000 & & $-4,486$ \\
\hline & $\begin{array}{c}\text { R\&D } \\
\text { headcount }\end{array}$ & , 130 & 1,980 & ,049 & , 130 & 1,980 \\
\hline & $\begin{array}{c}\text { R\&D } \\
\text { spending }\end{array}$ & , 169 & 2,591 & ,010 & ,167 & 2,591 \\
\hline & $\begin{array}{c}\text { New product } \\
\text { sales }\end{array}$ & , 167 & 2,449 & ,015 & , 169 & 2,449 \\
\hline & $\begin{array}{c}\text { Patent } \\
\text { production }\end{array}$ & ,252 & 3,890 & ,000 & ,255 & 3,890 \\
\hline & $\begin{array}{c}\text { New product } \\
\text { released }\end{array}$ & ,255 & 3,875 & ,000 & ,252 & 3,875 \\
\hline
\end{tabular}

\section{CONCLUSIONS}

To respond to increased market demands and steady growth of technology, organizations must have R\&D support with the purpose to keep step with technological change and achieve strong competitive positions [42]. Keeping in mind the constant information base for efficient $R \& D$ function, measuring the performance of $R \& D$ product development is becoming an important task for managers who require the achievement of high performance.

This topic is essential for managers because it provides a good basis for benchmarking with other firms, Also, the knowledge of R\&D product development KPIs creates the basis for setting a new target performance and improving the company's future performance. For academics it is important to provide a significant base for enabling further research into the same issues.

The methodology proposed in this study is used to determine the importance of different $R \& D$ product development KPIs on performance of manufacturing food companies in Serbia. The results of this paper show that three R\&D product development KPIs (new product sales, patent production and new product releases) have medium positive correlation related to ROA, ROE, EBITDA margin as company performances. Also, the results indicate a weak link between two $R \& D$ product development KPIs (R\&D headcount and R\&D spending) and company performance. All analysed R\&D product development KPIs have a significant impact on company performances, but new product releases and patent production have the strongest.

The limitations of this research are reflected in determining the significance of only selected $R \& D$ product development KPIs. Another limitation is reflected in the structure of respondents. Namely, respondents are general managers of companies, not R\&D managers. In addition, there are other limiting factors, such as the type of industry and the size of firms whose influence was not observed in this research. In addition to the mentioned limitations, whose impact we will attempt to correct in future research, one of the recommendations is to examine the correlation and impact of selected R\&D product development KPIs on performances of companies in the process at individual level, as well as at the level of individual projects.

\section{REFERENCES}

[1] Pandit, S., Wasley, C. E., \& Zach, T. (2011). The Effect of Research and Development (R\&D) Inputs and Outputs on the Relation between the Uncertainty of Future Operating Performance and R\&D Expenditures. Journal of Accounting, Auditing \& Finance, 26(1), 121-144. https://doi.org/10.1177/0148558X11400583

[2] Salim, R. A. \& Bloch, H. (2009). Business expenditures on R\&D and trade performances in Australia: is there a link? Applied Economics, 41(3), 351-361. https://doi.org/10.1080/00036840601007302

[3] Zedtwitz, M., Friesike, S., \& Gassmann, O. (2013). Managing R\&D and New Product Development. In M. G. Dodgson, Oxford Handbook of Innovation Management, 530-547. Oxford: Oxford University Press.

[4] Vorkapić, M., Radovanović, F., Ćoćkalo, D., \& Đorđević, D. (2017). NPD in Small Manufacturing Enterprises in Serbia. Tehnički vjesnik - Technical Gazette, 24(1), 327-332. https://doi.org/10.17559/TV-20150807185156

[5] Andrade Rojas, M. G., Ramirez Solis, E. R., \& Jun Zhu, J. J. (2018). Innovation and network multiplexity: R\&D and the concurrent effects of two collaboration networks in an emerging economy. Research Policy, 47 (6), 1111-1124. https://doi.org/10.1016/j.respol.2018.03.018

[6] Sher, P. J. \& Yang, P. Y. (2005). The effects of innovative capabilities and R\&D clustering on firm performance: the evidence of Taiwan's semiconductor industry. Technovation, 25(1), 33-43. https://doi.org/10.1016/S0166-4972(03)00068-3

[7] Chen, J. (2018, March 8). EBITDA Margin. Retrieved from: https://www.investopedia.com/terms/e/ebitda-margin.asp 
[8] Strukan, E., Nikolić, M., \& Sefić, S. (2017). Impact of Transformational Leadership on Business Performance. Tehnički vjesnik - Technical Gazette, 24(Suppl. 2), 435-444. https://doi.org/10.17559/TV-20150624082830

[9] Brigham, B. H. \& Fitzgerald, L. (2001). Controlling Managers and Organisations: The Case of Performance Measurement in a Regulated Water Company. Coventry: Centre for Management under Regulation: Warwick Business School.

[10] Tonchia, S. \& Quagini, L. (2010). Performance Measurement: Linking Balanced Scorecard to Business Intelligence . London: Springer. https://doi.org/10.1007/978-3-642-13235-3

[11] Hall, M. (2008). The effect of comprehensive performance measurement systems on role clarity, psychological empowerment and managerial performance. Accounting Organizations and Society, 33(2/3), 141-163. https://doi.org/10.1016/j.aos.2007.02.004

[12] Amaratunga, D. \& Baldry, D. (2002). Moving from Performance Measurement to Performance Management. Facilities, 20(5/6), 217-223. https://doi.org/10.1108/02632770210426701

[13] Parmenter, D. (2010). Key Performance Indicators: Developing, Implementing and Using Winning KPIs (2 ed.). New Jersey: John Wiley \& Sons, Inc.

[14] Stanojković, S. \& Cvetković, D. (2018). Evaluation of Interested Parties by Key Performance Indicators. Tehnički vjesnik - Technical Gazette, 25(Suppl. 1), 205-210. https://doi.org/10.17559/TV-20170528140157

[15] Kibira,D., Brundage, M., \& Feng, S. (2017). Procedure for Selecting Key Performance Indicators for Sustainable Manufacturing. Proceedings of the ASME 2017. 12th International Manufacturing Science and Engineering Conference - MSEC2017. https://doi.org/10.1115/MSEC2017-2877

[16] Lop, N. S., Ismail, K., Mohd Isa, H., \& Khalil, N. (2018). An Effective Approach Of Performance Measurement Systems (Pms) For Adoption In Construction Projects. Journal of Engineering Science and Technology, 13(12), 3951-3963.

[17] Wiktorsson, M., Andersson, C., \& Turunen V. (2018). Leading towards high-performance manufacturing Enabling indicators in early R\&D phases ensuring future KPI outcome. Procedia Manufacturing(25), 223-230 https://doi.org/10.1016/.jpromfg.2018.06.077

[18] Salimi, N. \& Rezaei, J. (2018). Evaluating firms' R\&D performance using best worst method. Evaluation and Program Planning, 66, 147-155. https://doi.org/10.1016/j.evalprogplan.2017.10.002

[19] Chiesa, V., Frattini, F., Lazzarotti, V., \& Manzini, R. (2009). Performance Measurement in R\&D: Exploring the Interplay Between Measurement Objectives, Dimensions of Performance and Contextual Factors. $R \& D$ Management, 39(5), 487-519. https://doi.org/10.1111/j.1467-9310.2009.00554.x

[20] Zhu, Z. \& Huang, F. (2012). The Effect of R\&D Investment on Firms' Financial Performance: Evidence from the Chinese Listed IT Firms. Modern Economy, 3(8), 915-919. https://doi.org/10.4236/me.2012.38114

[21] Tubbs, M. (2007). The Relationship between R\&D and Company Performance. Research-Technology Management, 50(6), 23-30. https://doi.org/10.1080/08956308.2007.11657470

[22] Lee, J., Whang, K., \& Hall Jr, E. H. (2009). A Comparative Approach to the Strategic Impact of $R \& D$ and Export Activity on Firm Economic Performance in Small Business Firms: U.S., Japan and Korea. ICSB World Conference Proceedings, 1-16. Washington DC.

[23] Ayaydin, H. \& Karaaslan, I. (2014). The Effect of Research and Development Investment on Firms' Financial Performance: Evidence from Manufacturing Firms in
Turkey. The Journal of Knowledge Economy \& Knowledge Management, 9(1), 23-39.

[24] Chumaidiyah, E. (2012). The Technology, Technical Skill, and R\&D Capability in Increasing Profitability on Indonesia Telecommunication Services Companies. Procedia Economics and Finance, (4), 110-119. https://doi.org/10.1016/S2212-5671(12)00326-7

[25] Ghaffar, A. \& Khan, W. A. (2014). Impact of Research and Development on Firm Performance. International Journal of Accounting and Financial Reporting, 4(1), 357-367. https://doi.org/10.5296/ijafr.v4i1.6087

[26] Ozturk, E. \& Zeren, F. (2015). The Impact of R\&D Expenditure on Firm Performance in Manufacturing Industry: Further Evidence From Turkey. nternational Journal of Economics and Research, 6(2), 32-36.

[27] Vander Pal, G. A. (2015). Impact of R\&D Expenses and Corporate Financial Performance. Journal of Accounting and Finance, 15(7), 135-149.

[28] Blasi, S., Caporin, M. \& Fontini, F. (2018). A Multidimensional Analysis of the Relationship Between Corporate Social Responsibility and Firms' Economic Performance. Ecological Economics, 147, 218-229. https://doi.org/10.1016/j.ecolecon.2018.01.014

[29] Lev, B., Sarath, B., \& Sougiannis, T. (2005). R\&D Reporting Biases and Their Consequences. Contemporary Accounting Research, 22(4), 977-1026. https://doi.org/10.1506/7XMH-QQ74-L6GG-CJRX

[30] Shu-Ching, C. \& Wenching, F. (2006). A Study on the Factors of Manufacturer Profitability: The Moderating Effect of Different Industries. Journal of American Academy of Business, 8(2), 138-144.

[31] Hargrave, M. (2019, July 3). Return on Assets - ROA. Retrieved from: https://www.investopedia.com/terms/r/returnonassets.asp

[32] Hargrave, M. (2019, June 20). Return on Equity - ROE. Retrieved from: https://www.investopedia.com/terms/r/returnonequity.asp

[33] Sraders, A. (2018, October 15). What Is an EBITDA Margin? Examples and How to Calculate. Retrieved from: https://www.thestreet.com/personal-finance/what-is-anebitda-margin-14744693

[34] Statistical Office of the Republic of Serbia. (2018). Statistical Yearbook. Belgrade: Statistical Office of the Republic of Serbia, 189.

[35] Ristić, Ž. (2011). Kvantitativna, kvalitativna i mešovita istraživanja: metodološki aspekti. Novi Sad: Univerzitet u Novom Sadu.

[36] Veričić, A. T., Ćorić, D. S., \& Vokić, N. P. (2013). Priručnik za metodologiju istraživačkog rada u društvenim istraživanjima. Zagreb: M.E.P. d.o.o. Zagreb.

[37] Goldense, B. (2014, April 28). Top 5 R\&D Product Development Metrics. Retrieved from: https://www.machinedesign.com/goldense-researchproduct-development/top-5-rd-product-developmentmetrics

[38] Tadić, J., Jevtić, J., \& Jančev, N. (2019). Modeling of critical profitability factors: Empirical research from food industry in Serbia. Economics of Agriculture (Ekonomika poljoprivrede), 66(2), 411-422. https://doi.org/10.5937/ekoPolj1902411T

[39] Coakes, S. (2013). SPSS 20.0 for Windows: Analysis without anguish. New Jersey: Wiley Publishin, Inc.

[40] Cohen, J. (1988). Statistical power analysis for the behavioral science. Hillsdale, New York: Lawrence Erlbaum Associates.

[41] Ho, R. (2013). Handbook of Univariate and Multivariate Data Analysis with IBM SPSS. New York: Chapman \& Hall/CRC. https://doi.org/10.1201/b15605

[42] Abbassi, M., Ashrafi, M., \& Tashnizi, E. S. (2014). Selecting Balanced Portfolios of R\&D Projects with 
Interdependencies: A Cross-Entropy Based Methodology.

Technovation, 34(1), 54-63.

https://doi.org/10.1016/j.technovation.2013.09.001

\section{Contact information:}

Jelena TADIĆ, PhD

Tadex Advisory

Simeona Piščevića 11/1, 21000 Novi Sad, Serbia

E-mail: ajelena83@gmail.com

Ivana MEDVED, PhD

(Corresponding author)

University of Novi Sad, Faculty of Economics,

Segedinski put 9-11, 24000, Subotica, Serbia

E-mail: ivana@ef.uns.ac.rs

Ranko BOJANIĆ, PhD

University of Novi Sad, Faculty of Technical Sciences,

Trg Dositeja Obradovića 6, 21000, Novi Sad, Serbia

E-mail: bojanicr@uns.ac.rs

Nemanja TASIĆ, PhD

University of Novi Sad, Faculty of Technical Sciences,

Trg Dositeja Obradovića 6, 21000, Novi Sad, Serbia

E-mail: nemanja.tasic@uns.ac.rs 